\title{
Assessment of the Physicochemical Properties of Selected Commercial Soaps Manufactured and Sold in Kenya
}

\author{
Onyango P. Vivian, Oyaro Nathan, Aloys Osano, Linda Mesopirr, Wesley Nyaigoti Omwoyo* \\ Department of Chemistry, Maasai Mara University, Narok, Kenya \\ Email: ${ }^{*}$ wesleyomwoyo16@gmail.com
}

Received 13 May 2014; revised 25 June 2014; accepted 7 July 2014

Copyright @ 2014 by authors and Scientific Research Publishing Inc.

This work is licensed under the Creative Commons Attribution International License (CC BY).

http://creativecommons.org/licenses/by/4.0/

(c) (i) Open Access

\section{Abstract}

Soap is sodium or potassium salt of fatty acid produced by saponification reaction. Soap is used on a day to day basis by households. The physicochemical properties of soaps determine their quality and hence determine their efficiency and their cleansing properties. It remains obscure the quality of the soaps that are sold in the local markets in Kenya and thus the need to assess them. Eight commercial washing soaps were analyzed for Matter insoluble in alcohol, moisture content, total fat matter, free caustic alkalinity, Percentage chloride, $\mathrm{pH}$ and Total alkali according to documented methods of analysis. Values of matter insoluble in alcohol ranged between $6.22 \%$ to $61.80 \%$, moisture content ranged between $10.91 \%$ to $22.69 \%$, total fat matter ranged between $22.64 \%$ to $70.51 \%$, free caustic alkali ranged between $0.00 \%$ to $0.06 \%$, percentage chloride ranged between $0.07 \%$ to $1.01 \%$, pH ranged between 10.63 to 11.71 and total alkali ranged between $0.00 \%$ to $0.99 \%$. This study showed that the free caustic alkalinity of all the analyzed soap samples were below the KEBS set limits hence no adverse effects on the cloth or skin, and the pH values for all analyzed soaps were within KEBS limits.

\section{Keywords}

Soap, Moisture Content, Total Fat Matter, Percentage Chloride, Saponification

\section{Introduction}

Soap may also be described as any water-soluble salt of those fatty acids which contain eight or more carbon atoms [1]. Based on its chemical properties as an anionic surface active agent or surfactant, soap is used to clean

\footnotetext{
*Corresponding author.
}

How to cite this paper: Vivian, O.P., Nathan, O., Osano, A., Mesopirr, L. and Omwoyo, W.N. (2014) Assessment of the Physicochemical Properties of Selected Commercial Soaps Manufactured and Sold in Kenya. Open Journal of Applied Sciences, 4, 433-440. http://dx.doi.org/10.4236/ojapps.2014.48040 
and wash skin and clothing. They are also used in textile spinning and are important components of lubricants. Soaps for cleaning are obtained by treating vegetable or animal oils and fats with a strong alkaline solution. Fats and oils are composed of triglycerides; three molecules of fatty acids are attached to a single molecule of glycerol [2]. The fatty acids; stearic acid, palmitic acid, myristic acid, lauric acid and oleic acid contribute to lathering and washing properties of the soaps [3]. Fats are solid esters of fatty acids and glycerin while oils are the liquid glycerol esters of fatty acids at room temperature. During saponification reaction of glycerides with alkalis, $\mathrm{NaOH}$ is used for solid or bar soaps and $\mathrm{KOH}$ is used for liquid soaps [4]. These are characteristically different from soaps made from divalent metals such as calcium, magnesium, iron or aluminum which are not water soluble [1]. Coconut oil is a source of lauric acid (12 carbons) which can be made into sodium laurate. This soap is very soluble and will lather easily even in sea water. Fatty acids with only 10 or fewer carbons are not used in soaps because they irritate the skin and have objectionable odours [1]. For centuries, soap was the only cleansing substance available. Shortage of some raw materials makes soap to be highly priced and only wealthy people could afford it [5]. It became affordable to other people only after the manufacture of sodium carbonate came in handy during the manufacture of soap [5]. At the end of the $19^{\text {th }}$ century, the first soap powder for laundry was made using sodium silicate as a builder [5]. Though the use of sodium or potassium carbonate leads to a hard or soft soap respectively, the chemical nature of the lipophilic part of soap plays the largest role in determining the performance of finished soap [5]. The physicochemical characteristic of soap depends on several factors which include the strength and purity of alkali, the kind of oil used and completeness of saponification. Such physicochemical characteristics include moisture content, total fat matter (TFM), $\mathrm{pH}$, free caustic alkalinity and percentage chloride [6]. The metals commonly used in soap making are sodium and potassium, which produce watersoluble soaps [1]. Good quality soap for cleansing purpose is one that strikes a balance in all the mentioned physicochemical parameters. The levels of the physicochemical properties in the Kenyan soaps remain obscure and thus the quality of individual soaps also remains unknown. Herein we report the levels of physicochemical parameters of selected bar soaps that are used for cleansing purposes and that are manufactured and sold in Kenyan markets.

\section{Materials and Methods}

\subsection{Experimental Design and Sample Collection}

Eight commercial bar soaps were purchased from Naivas, Suntec and Mureithi supermarkets in Narok town, Kenya in three replicates for each bar soap. The bar soaps were removed from the wrapper and chopped into small pieces. A one factor completely randomized design was adopted with types of bar soaps being the main factor.

\subsection{Analysis of the Physicochemical Properties of Soap}

Standard procedures as described by AOCS [7], were used for the analysis of physicochemical properties of soap with slight modifications as explained. For determination of $\mathrm{pH}, 10$ grams of the powdered bar soap were weighed and dissolved in distilled water and made up to $100 \mathrm{~mL}$. This was made up to prepare $10 \%$ soap solution. The $\mathrm{pH}$ of the soap solution was determined using a pH meter (Hanna $\mathrm{pH} 211$ microprocessor $\mathrm{pH}$ meter). Two grams of finished soap was dissolved in $10 \mathrm{~mL}$ of distilled water and retained till sample dissolved. The $\mathrm{pH}$ was determined with the same instrument.

For the determination of moisture content, 5 grams of samples was accurately weighed using analytical balance of sensitivity $0.1 \mathrm{mg}$ into dried tarred moisture dish in an oven for $2 \mathrm{hrs}$ and temperature of $101^{\circ} \mathrm{C}$ and repeated until a constant weight was reached. The \% moisture was calculated using the following formula:

$$
\% \text { moisture }=\frac{C_{S}-C_{L}}{C_{S}-C_{W}} \times 100
$$

where; $C_{W}=$ Weight of crucible, $C_{S}=$ Weight of crucible + sample, $C_{L}=$ Weight of crucible + sample after floating [7].

Free caustic alkali was determined by the method described by Milwidsky and Gabriel [8]. According to these method 5 grams of finished soap was weighed and dissolved in $30 \mathrm{~mL}$ of ethanol. Few drops of phenolphthalein indicator and $10 \mathrm{~mL}$ of $20 \% \mathrm{BaCl}_{2}$ were added. The resulting solution was then titrated against $0.05 \mathrm{M}$ $\mathrm{H}_{2} \mathrm{SO}_{4(\mathrm{aq})}$. 
Free Caustic Alkali-the volume of the acid obtained was calculated using the formula:

$$
\mathrm{FCA}=\frac{0.31}{W} \times V_{A}
$$

where; $V_{A}=$ Volume of acid, $W=$ Weight of soap.

In the determination of \% chloride, the method described by Onyegbado et al. [9], was followed. 10 grams of soap were weighed and made up to $100 \mathrm{~mL}$ of distilled water and heated to dissolve sample. The resulting solution was transferred into a $250 \mathrm{~mL}$ volumetric flask and $20 \mathrm{~mL}$ of $15 \%\left(\mathrm{Ca}\left(\mathrm{NO}_{3}\right)_{2}\right)$ added to it and shaken to dissolve the soap completely. Distilled water was added to the solution to the $250 \mathrm{~mL}$ mark. The solution filtered and methyl red added to $100 \mathrm{~mL}$ of the filtrate. The solution was titrated against $10 \mathrm{~N} \mathrm{H}_{2} \mathrm{SO}_{4(\mathrm{aq})}$ until a pink color was obtained. The resulting solution was titrated against $0.1 \mathrm{AgNO}_{3}$ using $\mathrm{K}_{2} \mathrm{Cr}_{2} \mathrm{O}_{7}$ as indicator till a brick red color was obtained [9]. The following formula was used for calculating the \% chloride.

$$
\% \mathrm{Cl}=\frac{\text { Titre volume }}{\text { Weight of soap }} \times 0.585
$$

The total alkali was determined by titrating excess acid contained in aqueous phase with standard volumetric $\mathrm{NaOH}$ solution as described in AOCS [7]. 10 grams of soap were weighed and $100 \mathrm{~mL}$ of neutralized alcohol added to it. $5 \mathrm{~mL}$ of $1 \mathrm{~N} \mathrm{H}_{2} \mathrm{SO}_{4(\mathrm{aq})}$ solution was added to the mixture and heated till the soap sample dissolved. Test solution was titrated against $1 \mathrm{~N} \mathrm{NaOH}$ using phenolphthalein indicator. The total alkali was obtained with the formula:

$$
\% \text { Total alkali }=\frac{V_{A}-V_{B}}{W} \times 3.1
$$

where: $V_{A}=$ Volume of acid, $V_{B}=$ Volume of base, $W=$ Weight of soap.

Determination of total fat matter followed a method described in AOCS [7], with slight modifications. The total fat matter test was carried out by reacting the different soaps with acid in the presence of hot ethanol and measuring the fatty acids obtained. About 10 grams of soap was weighed and $150 \mathrm{~mL}$ of warm neutralized ethanol was added and heated. The dissolved solution was then filtered and the residue dried in the oven at $110^{\circ} \mathrm{C}$ for one hour and weighed again. The total fat matter was obtained using the following formula.

$$
100-(M C+M I A) / 1.085
$$

where: $M C=$ Moisture content and MIA = Matter insoluble in alcohol.

Analysis of matter insoluble in alcohol was determined by a method described in AOCS [7], with modifications Five grams of soap sample were dissolved in $50 \mathrm{ml}$ hot ethanol and quantitatively transferred in a pre weighed filter paper. The residue was dried in the oven at $105^{\circ} \mathrm{C}$ for 30 minutes, cooled and weighed again then reading taken. The calculations were carried out by using the following formula.

$$
(W s-F P) / W \times 100
$$

where: $W s=$ Weight of sample + filter paper, $F P=$ Weight of filter paper, $W=$ Weight of the sample.

\section{Results and Discussions}

\subsection{Analysis of the Matter Insoluble in Alcohol}

The results obtained from the analysis of different physicochemical parameters of the different soaps are given in Table 1. From the values obtained in the analysis, white star soap had the highest level of matter insoluble in alcohol of $61.86 \% \pm 2.78 \%$ followed by shujaa soap which had $31.45 \% \pm 2.82 \%$, then Yellow star with a mean of $20.88 \% \pm 0.39 \%$ followed by Ndume with a mean of $19.87 \% \pm 6.73 \%$ then Jamaa with a mean of $19.86 \% \pm$ $1.42 \%$ and followed by White wash which had a mean of $15 \% \pm 3.23 \%$ and then Menengai which had a mean of $9.84 \% \pm 1.06 \%$ and finally Sunlight had the least matter insoluble levels of $6.22 \% \pm 0.34 \%$. The results obtained for White star and Shujaa were found to be very high as compared to the results obtained by Viorica et al. [5], of $20 \%-28 \%$ and that of Ogunsuyi and Akinnawo [10], that varied from 3.5\% - 14.80\% while the results for Yellow star, Ndume, Jamaa, compares well with the study done by Viorica et al., 2011 which ranged from 20\% to $28 \%$ of the matter insoluble in alcohol, and these results varied greatly with those obtained by Ogunsuyi and Akinnawo [10], of 3.5\% to $14.80 \%$. The results obtained for White wash, Menengai and Sunlight compares well 
Table 1. Physicochemical analysis of selected commercial soap in Kenya.

\begin{tabular}{cccccccc}
\hline $\begin{array}{c}\text { Commercial } \\
\text { name of soap }\end{array}$ & $\begin{array}{c}\text { Matter insoluble } \\
\text { in alcohol (\%) }\end{array}$ & $\begin{array}{c}\text { Moisture } \\
\text { content (\%) }\end{array}$ & $\begin{array}{c}\text { Total fat } \\
\text { matter (\%) }\end{array}$ & $\begin{array}{c}\text { Free caustic } \\
\text { alkalinity (\%) }\end{array}$ & $\begin{array}{c}\text { Percentage } \\
\text { (\%) chloride }\end{array}$ & pH & $\begin{array}{c}\text { Total alkali } \\
\text { (\%) }\end{array}$ \\
\hline Yellow star & $20.88 \pm 0.39$ & $17.04 \pm 9.79$ & $57.22 \pm 0.41$ & $0.01 \pm 0.005$ & $1.01 \pm 0.03$ & $11.01 \pm 0.02$ & $0.50 \pm 0.05$ \\
Shujaa & $31.45 \pm 2.82$ & $10.91 \pm 1.27$ & $53.12 \pm 1.86$ & $0.00 \pm 0.00$ & $0.17 \pm 0.04$ & $10.68 \pm 0.06$ & $0.00 \pm 0.00$ \\
White star & $61.86 \pm 2.78$ & $13.58 \pm 1.78$ & $22.64 \pm 2.30$ & $0.06 \pm 0.00$ & $0.35 \pm 0.03$ & $11.71 \pm 0.03$ & $0.86 \pm 0.00$ \\
Ndume & $19.87 \pm 6.73$ & $22.69 \pm 0.94$ & $52.95 \pm 7.02$ & $0.01 \pm 0.005$ & $0.51 \pm 0.03$ & $10.65 \pm 0.03$ & $0.12 \pm 0.05$ \\
Jamaa & $19.86 \pm 1.42$ & $16.84 \pm 0.52$ & $58.35 \pm 0.83$ & $0.05 \pm 0.008$ & $0.82 \pm 0.05$ & $11.44 \pm 0.03$ & $0.56 \pm 0.05$ \\
Sunlight & $6.22 \pm 0.34$ & $17.27 \pm 1.18$ & $70.51 \pm 0.81$ & $0.00 \pm 0.00$ & $0.09 \pm 0.02$ & $10.80 \pm 0.03$ & $0.00 \pm 0.00$ \\
Menengai & $9.84 \pm 1.06$ & $20.53 \pm 0.19$ & $63.87 \pm 0.96$ & $0.01 \pm 0.005$ & $0.80 \pm 0.04$ & $11.19 \pm 0.02$ & $0.99 \pm 0.05$ \\
White wash & $15.00 \pm 3.23$ & $17.49 \pm 0.55$ & $61.49 \pm 3.38$ & $0.00 \pm 0.00$ & $0.07 \pm 0.00$ & $10.63 \pm 0.01$ & $0.19 \pm 0.05$ \\
\hline
\end{tabular}

with the results obtained by Ogunsuyi and Akinnawo [10], of 3.4\% to 14.80\%. Matter insoluble in alcohol (MIA) is a parameter that is used to determine the purity of soap [5]. It is the measure of non-soap ingredients known as builders or fillers such as sodium silicate, sodium phosphate, sodium carbonate and minor constituents such as bleachers, whitening agents and fluorescing agents in the finished product. The soap with high MIA values suggests that it contained high level of impurities which may be attributed to the level of impurities of alkali used for producing the soap [5]. The slight difference in hardness could be accounted for by the presence of impurities which contributed to the bulkiness of soap [10].

\subsection{Analysis of Moisture Content}

Moisture content is a parameter that is used in assessing the shelf life of a product. High moisture content in soap would lead to reaction of excess water with un-saponified fat to give free fatty acid and glycerol in a process called hydrolysis of soap on storage. From the values obtained in the analysis, Ndume soap had the highest level of moisture content of $22.69 \% \pm 0.94 \%$ followed by soap which had $20.53 \% \pm 0.19 \%$, then White wash with a mean of $17.49 \% \pm 0.55 \%$, then Sunlight with a mean $17.27 \% \pm 1.18 \%$ and then Yellow star which had a mean of $17.04 \% \pm 9.79 \%$, then Jamaa with a mean of $16.84 \pm 0.52 \%$ followed by White star with a mean of $13.58 \% \pm 1.78 \%$ and finally Shujaa which had a mean of $10.91 \% \pm 1.27 \%$. The results obtained in this study for moisture content compares well with the study done by Viorica et al., 2011 (10\% - 16.2\%) and Kuntom et al. [11], (9\% - 16\%) for Shujaa soap, White wash and Jamaa, but were greatly different from that obtained by Osuji et al. [12], of $18.8 \%-22.5 \%$. The results obtained for Menengai soap $(20.53 \% \pm 0.19 \%)$ compares well with that of Osuji et al. [12]. The soap samples that fall within the limits of Encyclopedia of Industrial Chemical Analysis (10\% - 15\%) are Shujaa and White star only. However, all the moisture content values of this study are within the limits set by Kenya Bureau of Standards (22\% - 26\%). The results obtained for the moisture content of the soaps in this study are below those obtained by Ogunsuyi and Akinnawo [10], of 29.05\% and above that obtained by Ainie et al. [3], which had a ranged of (6\% - 8\%). These dissimilarities may be due to difference in the soap preparing methods though this was not investigated in this study. The moisture content value of Yellow star, Ndume, Jamaa, Sunlight, Menengai and White wash were above the set standards of moisture content but Shujaa and White star met the set Standards.

\subsection{The Total Fat Matter Content of the Commercial Soaps}

The results obtained in this study showed that Sunlight soap had the highest total fat matter (TFM) value of $70.51 \% \pm 0.81 \%$ followed by Menengai soap which had $63.87 \% \pm 0.96 \%$ then White wash with a mean of $61.49 \%$ $\pm 3.38 \%$ followed by Jamaa which had $58.35 \% \pm 0.83 \%$ then Yellow star with a mean of $57.22 \% \pm 0.41 \%$ then Shujaa with a mean of $53.12 \% \pm 1.86 \%$ and Ndume with a mean of $52.95 \% \pm 7.02 \%$ and finally White star which had a mean of $22.64 \% \pm 2.30 \%$. The results obtained in this study showed that total fat matter was below that of washing soaps obtained by Viorica et al., 2001 of 71\% - 84\% and Kuntom et al. [11], of 74\% - 92\%. These results obtained in this study for Ndume, Shujaa, Jamaa, Yellow star and White wash compares well with 
the results obtained by Viorica et al. [5], which varied from 34\% - 61\% of total fat matter and differed greatly with the results obtained by Mak-Mensah et al., 2011 which ranged between 63\% - 75\% and Hui, 1996 that ranged between $65 \%-70 \%$. The results of Sunlight and Menengai compare well with the results obtained by Mak-Mensah and Firempong [13], and Hui [14]. The TFM value for Jamaa soap tallies with the results obtained by Warra et al., 2014 of 58\% and also with the Ghanaian Standards of 59\% [13]. Sunlight soap values compares well with the results obtained by Osuji et al. [12], of 67.8\% - 71.8\% while Ndume and Menengai soaps almost compares with the results obtained by Ogunsuyi and Akinnawo [10] of 55.45\% and that of Beetseh et al. [15], of $62 \%$ respectively. The obtained total fat matter of sunlight soap in this study falls within the limits of results obtained by Eke et al. [16], of 66.74\% - 82.02\%. These differences in the TFM is responsible for high moisture content and the kinds and quantities of the used fatty materials and also perhaps due to the differences in the saponification method. The lower TFM value is due to presence of unreacted $\mathrm{NaOH}$ in the mixture [6]. However, dry skin needs soap which is high in TFM of $80 \%$. This rehydrates the skin making it smooth, and additionally the high oil content within the soap acts as a lubricant throughout the day [13].

\subsection{Analysis of Free Caustic Alkali in Commercial Soaps in Kenya}

Free caustic alkali is one of the parameters that determine the abrasiveness of any given soap [17]. This mostly results from improper or incomplete sapononification. From the current analysis, White star had the highest free caustic alkalinity value of $0.06 \%$ followed by Jamaa soap which had a mean of $0.05 \% \pm 0.008 \%$ then Menengai, Ndume and Yellow star soap that had a mean of $0.01 \% \pm 0.005 \%$ while Shujaa, Sunlight and White wash soap had no content of the free caustic alkali. This result obtained in the current study for White wash, Sunlight, Shujaa, Yellow star, Ndume and Menegai soap are similar to the results obtained by Ainie et al. [3], of $<0.1 \%$ for Malaysian soap, Osuji et al. [12], of 0.06\% - 0.09\%, Mak-Mensa and Firempong [13], of a range of $0.06 \% \pm$ $0.002 \%$ and those of Egyptian Standards of $0.06 \%$. The obtained results for free caustic alkalinity of the analyzed soap samples are below those obtained by Ogunsuyi and Akinnawo [10], of $0.09 \%-0.25 \%$ for laundry and $0.2 \%$ for toilet soap, $2.95 \%$ obtained by Beetseh et al. [15], and $1.24 \%$ of free caustic alkalinity obtained by Taiwo et al. [18]. This study showed that the free caustic alkalinity of all the analyzed soap samples were below the Kenya Bureau of Standards set limits, hence the amount of free caustic alkalinity in the analyzed soap samples had no adverse effect on cloth or skin.

\subsection{Determination of Percent Chloride in Selected Kenyan Soaps}

The determination of percentage chloride levels in soap is important as excess amount causes soaps to crack [18]. From this study, Yellow star had the highest chloride content of $1.01 \% \pm 0.03 \%$ followed by Jamaa which had a mean of $0.82 \% \pm 0.05 \%$ then Menengai with a mean of $0.80 \% \pm 0.04 \%$ then Ndume with a mean of $0.51 \% \pm$ $0.03 \%$ followed by White star which had a mean of $0.35 \% \pm 0.03 \%$ then Shujaa which had a mean value of $0.17 \%$ $\pm 0.04 \%$ then Sunlight with a mean of $0.09 \% \pm 0.02 \%$ and finally White wash which had a mean of $0.07 \%$. This result obtained in the current study for Shujaa and White star soap are similar to the results obtained by Viorica et al. [5], of $0.16 \%-0.48 \%$ and the results for Menengai, Jamaa and Yellow star compares with that obtained by Taiwo et al. [5], of $0.9 \%$. The results of percentage chloride for all the analyzed soap samples was below those obtained by Mak-Mensah and Firempong [13] of 1.15\%, and those of the Ghanaian Standards value of 1.5\% [19]. The reason for high chloride content of the soap is due to the use of chlorinated water to dissolve $\mathrm{NaOH}$ pellets [18].

\subsection{Analysis of $\mathrm{pH}$ in the Soap Samples}

White star had the highest $\mathrm{pH}$ value of $11.71 \pm 0.03$ followed by Jamaa with a value of $11.44 \pm 0.03$ then Menengai with a value of $11.19 \pm 0.02$ then Yellow star with a value of $11.01 \pm 0.02$ while Sunlight had a value of $10.80 \pm 0.03$ followed by Shujaa with a value of $10.68 \pm 0.06$ then Ndume with a value of $10.65 \pm 0.03$ and finally White wash which had a value of $10.63 \pm 0.01$. The results obtained in the current study for Yellow star, Shujaa, Ndume, Sunlight and white wash soap compares with that obtained by Oyedele [20], of a pH range of 9 - 11. The $\mathrm{pH}$ values obtained for Yellow star, White star, Jamaa and Menengai were found to be high as compared with the results obtained by Beetseh et al. [15], of $\mathrm{pH}$ value of 9, by Warra et al. [19], of $\mathrm{pH}$ value of 10.72, Viorica et al. [5], who had a range of $\mathrm{pH}$ between 5.5 - 8.0, Mak-Mensah and Firempong [13] who had a 
$\mathrm{pH}$ value of 10.4, Warra et al. [19], of $\mathrm{pH}$ value of 9.38 for cotton seed oil soap and Tan [21], who had a $\mathrm{pH}$ range of $7.84-10.55$. High $\mathrm{pH}$ values are as a result of incomplete hydrolysis resulting from saponification process. It can be overcome by adding excess fat or oil or any other super fatting agent to reduce the harshness of soap [19]. This indicates that the analyzed soaps are corrosive to the skin. As the salt of a weak acid (fatty acid) and a base, soap is alkaline to aqueous solution. Alkaline substances neutralize the body's protective acid mantle that acts as a barrier against bacteria and viruses. Healthy skin has a pH of 5.4 to 5.9 [13]. The alkalinity favors detergency [22]. This study indicates that the $\mathrm{pH}$ values of Shujaa (10.68 \pm 0.06$)$, Ndume (10.65 \pm 0.05$)$ and White wash $(10.63 \pm 0.01)$ were below the KEBS limits hence had no adverse effect while the $\mathrm{pH}$ values of White star (11.71 \pm 0.03$)$, Menengai (11.19 \pm 0.02$)$, Yellow star (11.01 \pm 0.02$)$, Jamaa (11.44 \pm 0.03$)$ and Sunlight were within the set KEBS limits.

\subsection{Total Alkali of the Commercial Soaps}

Total alkalinity is the total alkaline material present in soap. They include alkaline components such as hydroxides, sodium (II) oxide, carbonates and bicarbonates. Menengai soap had the highest value of $0.99 \% \pm 0.05 \%$ total alkali followed by white star which had a value of $0.86 \%$ then Jamaa which had $0.56 \% \pm 0.05 \%$ while Yellow star had a mean of $0.50 \% \pm 0.055 \%$ followed by White wash with a mean of $0.19 \% \pm 0.05 \%$ then Ndume with a mean of $0.12 \% \pm 0.055 \%$ and finally Shujaa and Sunlight which had $0.00 \%$ total alkali. The results obtained in the current study for Jamaa soap compares with that obtained by Warra et al. [19], of 0.57\%. The total alkali results obtained for Menengai and White star were found to be higher compared to the results obtained by Mak-Mensah and Firempong [13] of value of $0.24 \%$ and that of $0.34 \%$ for the Ghanaian Standards [13].

\subsection{Assessment of Similarities in the Quality of the Selected Soaps}

The differences and similarities in the selected soap samples were assessed using a dentrogram for clustering purposes (Figure 1). From the dendrogram, Sunlight and White wash soap are similar in overall quality whereas Menengai, Ndume, Jamaa and Yellow star soap fall in the same cluster. Shujaa soap fall in a cluster of its own while White star is dissimilar from all the soap samples. These results stem from the analyzed physicochemical properties of the the different soap samples.

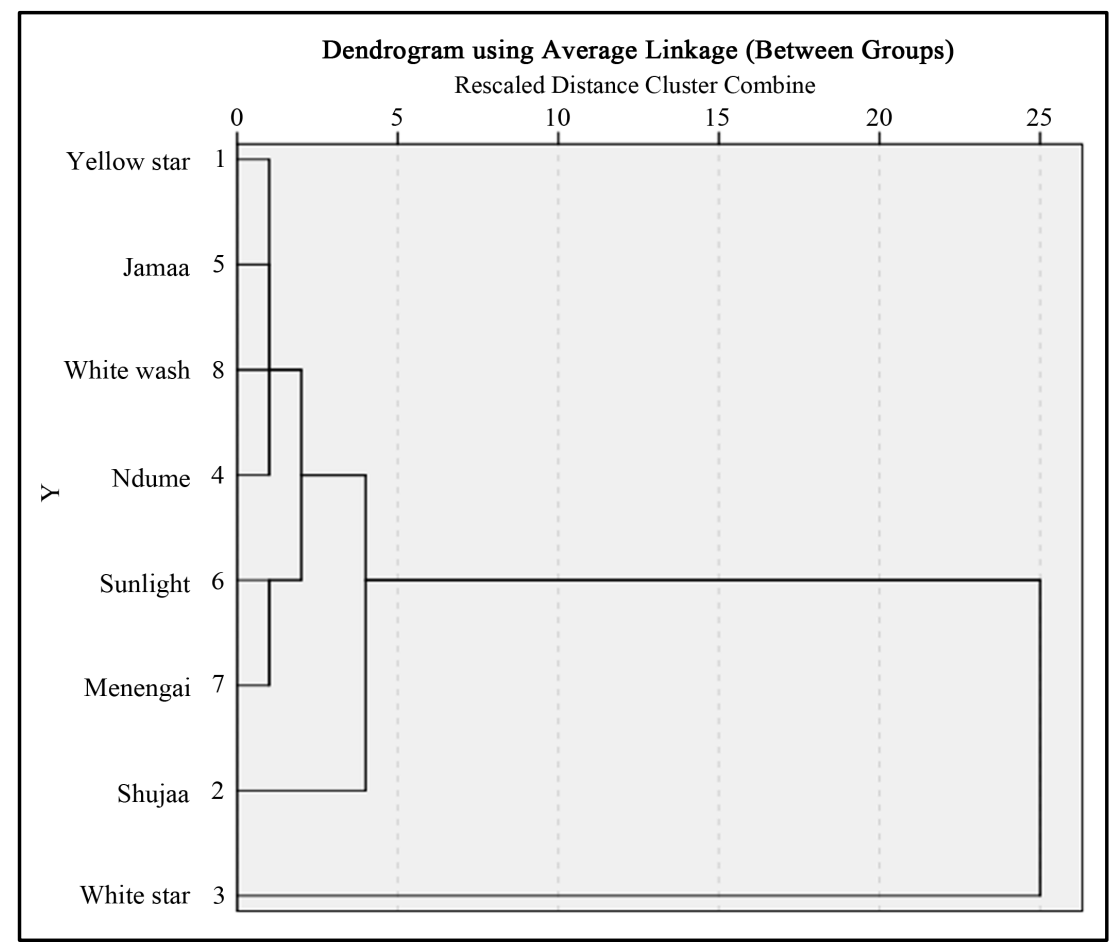

Figure 1. Dendrogram showing the different clusters of different bar soaps. 


\section{Conclusion}

The results obtained in this study were compared with the data in the literature and it could be concluded that; Sunlight, Menengai and White wash were grade I soaps, Jamaa, Shujaa, Yellow star and Ndume were grade II soaps and White star was a grade III soap. The translated grades of white wash, Jamaa, Shujaa and Ndume tallied with that indicated on the packaging while white star, Menengai, Yellow star and Sunlight had no grade number on the packaging. It is necessary to choose soap that strikes a balance among the physicochemical parameters. Soap that has minimal matter insoluble in alcohol as this will be pure, minimal moisture content as this will increase the shelve life its shelve life and high amounts of total fat matter for lubricating the skin while washing. It should also have lower levels of caustic alkalinity to reduce adverse effects on skin and cloth and higher $\mathrm{pH}$ values make the soap basic and lather easily. Any soap that balances on these parameters in termed to be a high quality soap.

\section{Acknowledgements}

The authors express gratitude to the technical staff, Department of Chemistry, Maasai Mara University for their support in sampling, experimentation and analysis. Much appreciation also goes to the Department of Chemistry, Jomo Kenyatta University of Agriculture and Technology where part of the analysis was done. This research was funded by Maasai Mara University through the Department of Physical Sciences.

\section{References}

[1] Chalmers, L. and Bathe, P. (1978) Chemical Specialist, Domestic and Industrial. 2nd Edition, George Godwin, UK, $1-15$.

[2] Kirk-Othman (1963) Detergency, Soap and Surfactants. Encyclopedia of Chemical Technology. Interscience, New York.

[3] Ainie, K., Hamirin, K. and Peang-Kean, L. (1996) Chemical and Physical Characteristics of Soap Made from Distilled Fatty Acids of Palm Oil and Palm Kernel Oil. Journal of American Oil Chemists' Society, 73, 105-108. http://dx.doi.org/10.1007/BF02523455

[4] Shoge, M. (2011) Quality of Soaps Using Different Oil Blends. Journal of Microbiology and Biotechnology Research, 1, 29-34.

[5] Viorica, P., Alina, S. and Simona, D. (2011) Quality Control and Evaluation of Certain Properties for Soap Made in Romania. Journal of Scientific Study and Research, Chemistry and Chemical Engineering, Biotechnology, Food Industry, 12, 257-261.

[6] Roila, A., Salmiah, A. and Razmah, G. (2001) Properties of Sodium Soap Derived from Palm-Based Dihydroxystearic Acid. Journal of Oil Palm Research, 1, 33-38.

[7] American Oil Chemists' Society (AOCS) (1997) Official and Recommended Practices of the AOCS. 7th Edition, AOCS Press Publication, Champaign.

[8] Milwidsky, B.M and Gabriel, D.M. (1994) Detergent Analysis: A Handbook for Cost-Effective Quality Control. Micelle Press, London, 160-161.

[9] Onyegbado, C.O., Lyagba, E.T. and Offor, O.J. (2002) Solid Soap Production Using Plantain Peels Ash as Source of Alkali. Journal of Applied Science and Environmental Management, 3, 73-77.

[10] Ogunsuyi, O. and Akinnawo, C. (2012) Quality Assessment of Soaps Produced from Palm Bunch Ash-Derived Alkali And Coconut Oil. Journal of Applied Science and Environmental Management, 16, 363-366.

[11] Kuntom, A., Ahmad, I., Kifli, M. and Shariff, Z.M. (1999) Chemical and Physical Characteristics of Soap Made from Distilled Fatty Acids of Palm Oil and Palm-Kernel Oil. Journal of Surfactants and Detergents, 2, 325-329. http://dx.doi.org/10.1007/s11743-999-0084-5

[12] Osuji, C.N., Akunna, T.O. and Ahaotu, E.O. (2013) Use of Palm Oil Sludge in Toilet Soap Production. International Journal of Applied Sciences and Engineering, 1, 73-78.

[13] Mak-Mensah, E. and Firempong, C. (2011) Chemical Characterization of Toilet Soap Prepared from Neem (Azadirachta indica A. Juss) Seed Oil. Asian Journal of Plant Science and Research, 1, 1-7.

[14] Hui, H.Y. (1996) Soap. In: Bailey’s Industrial Oil and Fat Products, John Wiley and Sons Inc, New York, 93.

[15] Beetseh, C. and Anza, M. (2013) Chemical Characterization of Black Soap (Chahul Mtse) Made by Using Cassava Peels Ashes (Alkali Base) and Palm Oil in North Central Zone of Nigeria. Journal of Chemical Characteristics of Local Black Soap, 3, 82-93. 
[16] Eke, U.B., Dosumu, O.O., Oladipo, E. and Agunbiade, F. (2004) Analysis of Locally Produced Soap Using Sheabutter oil (SBO) Blended with Palm-Kernel Oil (PKO). Nigerian Journal of Science, 38 19-24.

[17] Onyekwere, C. (1996) Cassava Peels Ash: An Alternative Source of Alkali in Soap Production. BEng Thesis, Department of Chemical Engineering, University of Port-Harcourt, Port-Harcourt, 1-33.

[18] Taiwo, A., Oluwadare, I., Shobo, A. and Amolegbe, S. (2008) Physical and Chemical Characteristics of Soap. Scientific Research Essay, 3, 515-517.

[19] Warra, A., Wawata, I., Gunu, S. and Atiku, F. (2011) Soap Preparation from Soxhlet Extracted Nigerian Cotton Seed Oil. Pelagia Research Library, 2, 617-623.

[20] Oyedele, A.O. (2002) The Skin Tolerance of Shea Fat Employed as Excipient in Topical Preparations. Nigerian Journal of Natural products and Medicine, 66, 26-29.

[21] Tan, Y.A., Ong, S.H., Berger, K., Oon, H. and Poh, B. (1985) A Study of the Cause of Rapid Colour Development of Heated Refined Palm Oil. Journal of American Oil Chemical Society, 62, 999-1006. http://dx.doi.org/10.1007/BF02935701

[22] Kaoru, T. (1998) Surface Activity: Principles Phenomena and Application. Academic Press, San Diego, 21-22. 
Scientific Research Publishing (SCIRP) is one of the largest Open Access journal publishers. It is currently publishing more than 200 open access, online, peer-reviewed journals covering a wide range of academic disciplines. SCIRP serves the worldwide academic communities and contributes to the progress and application of science with its publication.

Other selected journals from SCIRP are listed as below. Submit your manuscript to us via either submit@scirp.org or Online Submission Portal.
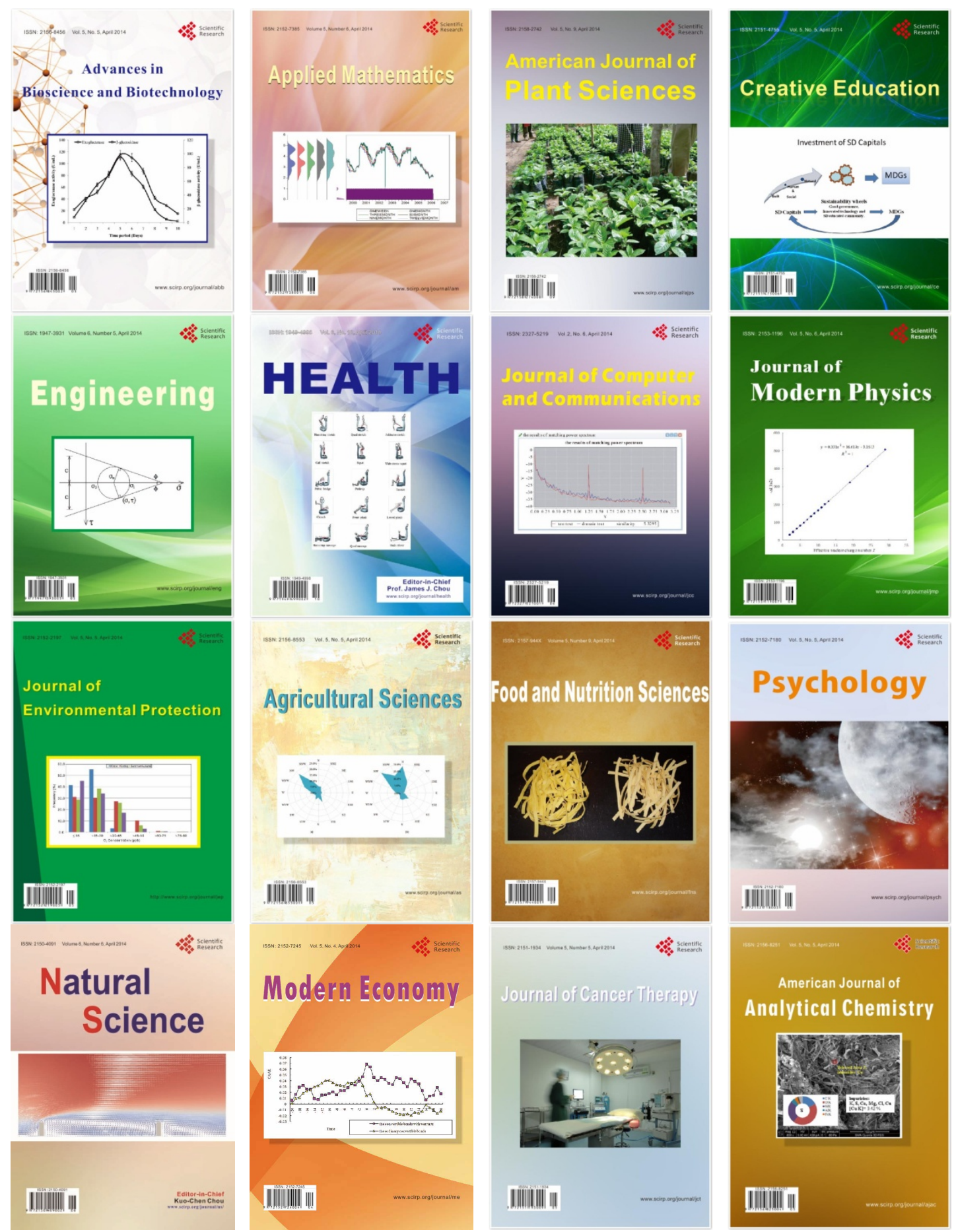